\title{
The Relationship between Language and Cognitive Development and Its Relevance for Infants' Mental Ability: Longitudinal Mediation Effects of Fine Motor Development
}

\author{
Mi-Ra Chunga, Soon-Hang Lee ${ }^{\mathrm{b}}$, Jong-Hoon Kim ${ }^{\mathrm{c}}$ \\ ${ }^{a}$ Department of Early Childhood Education, Gachon University, Seongnam, Korea \\ ${ }^{b}$ Sesalmaul SSK Research Center, Gachon University, Seongnam, Korea \\ ${ }^{c}$ Department of Children and Family, Gyeongnam National University of Science and Technology, Jinju, Korea
}

\author{
Correspondence: Soon-Hang Lee, PsyD \\ Sesalmaul SSK Research Center, Gachon University, \\ 1342 Seongnam-daero, Sujeong-gu, Seongnam \\ 13120, Korea \\ Tel: +82-31-724-4402 \\ Fax: +82-31-724-4403 \\ E-mail: dynamic9@hanmail.net
}

Received: October 5, 2017

Revised: November 10, 2017

Accepted: November 17, 2017

This study was supported by a National Research Foundation of Korea Grant (No. NRF-2016S1A3A295502)

\begin{abstract}
Objectives: Based on both prior theoretical and empirical research, this paper tested the proposition that fine motor development longitudinally mediates the effect of infants' language and cognitive development on later mental ability. Methods: Three data sets from 6 months to 12 months of 114 infants were analyzed with the cross-lagged panel model. The participants'language and cognitive development were assessed through K-ASQ at 6 months and 9 months, and their mental ability (MDI) was assessed by K-BSID-II at 12 months. Results: The cross-lagged panel model using PATH analysis indicated the development of language and cognitive ability was stable over 6 months. Fine motor development at 9 months had a full mediating effect on cognitive development at 6 months on MDI at 12 months. Fine motor development at 9 months had a partially mediated effect on language development at 6 months on MDI at 12 months. When language development was included in the predictor of MDI, cognition was no longer significantly associated with later $\mathrm{MDI}$, suggesting that language plays an important role in the cognition-MDI link. Conclusion: Because fine motor development partially mediated the effect of language development on MDI, early intervention efforts should target both language and fine motor development.
\end{abstract}

Keywords: Language development, Cognitive development, Fine motor development, Longitudinal mediation analysis, Infant mental ability
인간의 발달은 유기적으로 이루어진다(Siegel, 2012). 각 영역의 발달은 독립적으로 이루어지는 것이 아니라 다른 영역의 발달과 유 기적으로 연계되어 총체적(holistic)으로 이루어진다(Bornstein \& Lamb, 2011; Damon \& Lerner, 2006). 언어발달 역시 다른 영역의 발달에 의해 영향을 받기도 하고 다른 영역의 발달에 영향을 미치 기도 하며 유기적으로 발달한다(Bates, Benigni, Bretherton, Camaioni, \& Volterra, 1979; Kelly \& Martin, 1994; MacWhinney, 1987). 이에 본 연구에서는 영아기의 언어발달을 인지발달 및 소근 육운동발달과의 관계에서 종단적으로 살펴보고, 특히 발달 영역
간의 이러한 종단적 관련성이 12 개월의 영아기 지능에 어떻게 영향 을 미치는지를 살펴보고자 한다.

생후 6-12개월은 언어발달 측면에서 옹알이가 점차 정교화되고 관습적인 신호를 인식하고 표현하며 의사소통 의도가 발달하는 매 우 중요한 시기이다(Hoff, 2005; Owens, 2012). 최근 연구들은 이 시기의 언어발달이 인지발달(Abbot-Smith \& Tomasello, 2006; Bates et al., 1979; Christie \& Gentner, 2012) 및 소근육운동발달 (Benassi et al., 2016; Iverson, 2010; Wang, Lekhal, Aarø, \& Schjølberg, 2014)과 상호 관련성을 지니며, 영아기 지능(Dale, Bates, Rez- 
nick, \& Morisset, 1989; Molfese \& Acheson, 1997)에도 주요한 영 향을 미침을 보고하고 있다. 그러나 대다수의 선행연구들이 두 영 역 간의 상호관련성만을 살펴보았을 뿐 이들 영역들 간의 구조적 관계를 종단적으로 살펴보지 못했다는 한계점을 지닌다. 이에 본 연구에서는 언어, 인지, 소근육운동발달 간의 관계를 자기회귀교 차지연 모델(autoregressive and cross-lagged panel model)에 기초 하여 종단적으로 살펴보고자 하였다.

지능이란 환경에 효과적으로 적응하도록 도와주는 지적 기능 (Piaget, 1970)으로, 사고, 기억, 문제해결, 범주화, 언어 등 정신능력 (mental ability)의 개인차를 측정한다(Reznick, Corley, \& Robinson, 1997). 최근 정보처리 이론에 기반한 영아 연구가 활발해지면 서 영아기 지능에 대한 관심이 높아지고 있다. 특히 생의 초기 영아 기 지능이 이후의 지능과 정적인 관련성을 보일 뿐 아니라(Blaga et al., 2009) 생후 1년 동안의 영아기 지능이 이후의 지능을 예측할 수 있다는 연구결과들이 발표되면서(Rose, Feldman, \& Jankowski, 2004; Rose, Feldman, Jankowski, \& Van Rossem, 2012), 지능 안정 성의 기원으로서 영아기 지능에 관심이 모아지고 있지만, 아직 영아 기 지능의 구조와 발달에 대한 연구는 미비한 실정이다. 그나마 12 개월 영아의 지능 구조에 대한 몇 가지 선행연구들을 찾아볼 수 있 는데, Burns, Burns와 Kabacoff (1992)는 영아기 지적 능력을 평가 하는 대표적인 도구인 베일리영유아발달검사 2판(Bayley Scales of Infant Development-II, BSID-II)의 정신발달지수(Mental Developmental Index, MDI)를 요인분석하여 12 개월 영아의 지능 구조 가 소근육운동, 언어, 기억으로 구성되어 있다고 보고하였다. Gyurke, Lynch, Lagasse와 Lipsitt (1992) 역시 BSID-II의 MDI를 요인 분석하여 12 개월의 지능 구조가 소근육운동, 지각/운동, 언어로 구 성되어 있다고 보고하였다. 그러나 아직 12 개월 영아의 지능이 어 떠한 경로로 어떻게 발달하는지에 대한 연구는 부족한 상황이다. 이에 본 연구에서는 6개월과 9 개월의 언어, 인지(지각과 기억 포함), 소근육운동 능력이 어떠한 경로로 12 개월 영아기 지능에 영향을 미치는지를 종단적으로 살펴보고자 하였다.

전통적으로 지능은 인지발달-본 연구에서는 지능과 인지를 구 분하여 사용하였는데, 지능은 언어능력과 비언어적 인지능력을 포 함하는 정신능력(mental ability)을 말하며(Dale et al., 1989; Kohen-Raz, 1967; Molfese \& Acheson, 1997; Reznick et al., 1997), 인 지는 비언어적 인지능력을 지칭하였다-과 관련하여 연구되어 왔 다. 영아기 지능을 측정하는 발달검사들은 기억, 습관화, 재인, 신기 성 선호 등의 비언어적 정보처리 문항들을 포함하거나(Bayley, 1993, 2006; Fagan, Holland, \& Wheeler, 2007), 대상 영속성 같은 비언어 적 문제 해결 과제를 포함하고 있다(Bayley, 1993, 2006; Squires,
Potter, \& Bricker, 1999; Uzgiris \& Hunt, 1975). 이는 영아기 지능의 주요 구성요소에 비언어적 인지능력이 포함되어 있음을 나타낸다 (Rose et al., 2004). 또한 비언어적 정보처리를 측정함으로써 이후 의 지능을 예측하는 연구들도 지속적으로 수행되어 왔다. Rose 등 (2012)은 주의, 처리속도, 기억, 표상능력 등의 4가지 정보처리 과제 로 측정한 영아 인지능력이 만 11 세의 지능을 예측할 수 있음을 보 고하였으며, Fagan 등(2007)은 생후 6-12개월 영아의 주의능력이 만 21 세의 지능과 정적 상관이 있음을 주장하였다. 그 외 여러 연구 자들도 영아기 습관화/재인기억은 2세 이전 영아기 지능과 상관이 있음을 보고하였다(Colombo, Mitchell, Dodd, Coldren, \& Horowitz, 1989; Slater, Cooper, Rose, \& Morison, 1989). 국내 연구에서도 6 개월의 습관화 능력은 17 개월의 영아기 지능을 예측할 수 있으며 (Sung, Bea, Kwak, Chang, \& Sim, 2005), 영아기 대상 영속성은 이 후 인지능력과 정적으로 상관이 있음을 밝히고 있다(Sung \& Bea, 2004).

한편, Vygotsky (1962), Bruner (1977), Shatz (1994) 등이 인지발 달에서 언어가 중요한 역할을 한다는 이론을 제안한 이래, 언어는 아동기 및 성인 지능의 구성 요인으로 오랫동안 연구되어 왔다(예: Stanford-Binet 검사의 언어적 추론, Wechsler 검사의 언어성 검사). 하지만 영아기 지능을 구성하는 요인으로 언어가 포함되어 연구가 된 것은 최근의 일이다. Reznick 등(1997)은 영아기 지능을 언어와 인지(비언어)로 분리하는 것이 유용하다고 제안하였고, 이후 많은 학자들이 영아기 지능의 한 요소로서 언어영역을 인지영역과 구분 하여 측정하였을 때 유아 및 아동기 지능을 더 안정적으로 예측할 수 있다고 주장하였다(Dale et al., 1989; Kohen-Raz, 1967; Molfese \& Acheson, 1997). 이에 베일리영유아발달검사 3판에서도 언어영역 을 인지영역과 구분하여 독자적인 영역으로 세분화하였고, 이후 지능과의 안정성이 더욱 상승되는 결과가 보고되었다(Bayley, 2006).

더불어, 사물을 획득하고 조작하기 위해 손으로 수행하는 운동 기술인(Case-Smith, 1996) 소근육운동도 영아기 지능의 주요 구성 요인으로 제안되어 왔다(Burns et al., 1992; Gyurke et al., 1992). 소 근육운동은 시각과의 협응을 통해 섬세하고 정확한 손동작을 사 용할 수 있는 능력을 의미하므로 사물을 탐색하고 조작하는 활동 인 인지발달과 밀접한 관련성이 있으며(Wijnroks \& van Veldhoven, 2003), 1 세 영아의 운동발달 수준은 1-4세의 영유아기 지능과 관련 있음이 보고되었다(Burns, O'Callaghan, McDonell, \& Rogers, 2004).

최근 연구에서는 체화된 인지(embodied cognition) 관점에서 인 지 및 언어발달 경로를 설명하고 있다(Iverson, 2010; Johnson, 1987; Lee, 2010). 체화된 인지란 몸과 마음을 구분하던 전통적인 데카르 트적 이분법에서 탈피하여, 구체적인 몸을 가지고 환경과 상호작용 
하면서 적응하는 ‘행위’로서의 '마음'에 초점을 둔다(Bem \& Keijzer, 1996; Lee, 2010). 행위는 환경(상황)에 대한 지각을 내포하고 있 으므로, 행위를 연구하는 것은 그 환경에 대한 마음을 연구하는 것 이다. 따라서 이 관점에서는 어떻게 마음 혹은 인지가 발생하는지 를 탐색하기 위해서 신체 행위에 '체화되어 있는 인지' 혹은 몸짓에 ‘체화되어 있는 언어' 등을 연구 주제로 한다(Iverson, 2010; Iverson \& Thelen, 1999; Parladé \& Iverson, 2011; Volterra, Caselli, Capirci, \& Pizzuto, 2005). 본 연구에서는 영아기 지능을 측정하기 위해 K$\mathrm{BSID}-\mathrm{II}$ 의 $\mathrm{MDI}$ 에 초점을 두고 있으므로 대근육운동보다는 소근 육운동(Dale et al., 1989; Kohen-Raz, 1967; Molfese \& Acheson, 1997; Reznick et al., 1997)과의 관계에 중점을 두고 체화된 인지를 살펴보고자 한다.

먼저, 영아기 인지발달과 지능과의 관계에서 운동발달의 관련성 을 살펴보면, 영아는 감각운동적으로 환경과 상호작용하면서 새로 운 운동기술을 습득하고 정교화하게 되는데, 이는 세상을 탐색하 고 조작하는 방식의 변화를 가져온다. 체화된 인지와 지능 간의 관 계에 대한 이론적 기반은 Piaget (1970)의 감각운동기나 Gibson (1982)의 지각발달이론으로 거슬러 올라간다. Piaget (1970)는 2세 이전의 영아들은 감각운동적 조작 활동을 통해 지능이 발달한다 고 보았으며, Gibson (1982) 또한 행위와 지각 간의 역동적 상호작 용을 통해 지각이 발달한다고 보았다. 즉, 영아는 주변 환경에서 제 공하는 지각적 정보를 토대로 자신의 행위를 결정하며, 또한 행위 를 하면서 오는 피드백을 토대로 다시 자신의 행위를 조절해간다. 관련 선행연구를 살펴보면, Bushnell과 Boudreau (1993)는 영아의 운동 능력이 발달하면서(예: 잡기 방식의 변화) 대상을 촉각적으로 탐색하는 방식을 변화시키고(예: 움켜쥐기, 반복적인 움직임, 양 손 으로 조작하기 등), 이는 다시 대상에 대한 지각을 변화시킨다(예: 딱딱한 정도나 질감 지각-대상을 흔들거나 두드리기-대상 형체의 정교한 탐색)는 것을 증명하였다. 발달초기에 영아는 촉각으로 대 상을 탐색하고 지각하게 되는데(Bushnell \& Boudreau, 1993), 이때 의 지각발달은 촉각적 행위가 체화된 결과라고 할 수 있다. 또한 Campos와 동료들(Biringen, Emde, Campos, \& Appelbaum, 1995; Campos et al., 2000)도 팔 뻗기(reaching)와 같은 운동능력의 발달 이 인지적 탐색 방식의 변화와 밀접한 관련성이 있다고 제안하였다. 즉, 6 개월 이전의 영아들은 장난감에서 소리가 나거나 움직이거나 성인이 생기 있게 반응해주는 등 눈에 띄는 감각적 변화가 있어야 대상에 관심을 보이게 되나, 6 개월 이후가 되면 팔 뻗기, 잡기, 만지 기 등의 눈-손의 협응 능력이 발달하면서 움직이지 않는 장난감이 나 대상에 대한 흥미가 증가하게 된다고 주장하였다.

또한 체화된 인지 관점에서는 언어체계 역시 체화되어 발달하기
때문에 언어발달도 몸이라는 맥락에서 이해할 필요가 있음을 강조 한다. 특히 몸짓의 발달은 운동발달과 언어발달의 연계성을 보여 주는 대표적인 영역이다. 몸짓은 모든 문화권에서 나타나는 보편적 인 의사소통 양식으로 언어 발화와 밀접히 관련되어 있다(McNeill, 1992). 영아는 6개월 이후부터 자신의 의도를 보다 명확하고 효율 적으로 전하기 위해서 몸짓을 사용하기 시작한다. 이때부터 몸짓 은 말소리(speech)와 밀접한 관련성을 지니면서 발달한다. 체화된 언어발달을 종단적으로 연구한 Thelen (1979)에 따르면, 리드미컬 한 팔과 손의 움직임(예: 손 흔들기, 두드리기 등)은 생후 28주경에 그 빈도가 가장 높아지는데, 리드미컬한 반복적인 옹알이(예: 가가 가, 바바바 등) 역시 이 시기에 나타나는 것에 주목하였다(Koopmans-van Beinum \& van der Stelt, 1986; Oller \& Eilers, 1988). 딸 랑이를 흔드는 리드미컬한 팔 움직임은 옹알이를 시작하기 전에는 적게 나타나다가 옹알이를 시작하면서 급증하고 옹알이가 익숙해 지면서 다소 감소하는데(Ejiri, 1998; Iverson, Hall, Nickel, \& Wozniak, 2007; Locke, Bekken, McMinn-Larson, \& Wein, 1995), 이는 소리발성과 팔움직임이 서로 연계되어 나타나며 언어와 운동발달 이 밀접하게 관련되어 있음을 보여준다. 9 개월 이후에는 가리키기, 보여주기, 요구하기 등과 같은 의사소통적 몸짓이 증가하고 말소리 를 통한 소통은 다소 감소되지만 여전히 몸짓과 말소리는 긴밀한 관련성을 보이면서 발달한다. Bates 등(1979)의 연구에 의하면, 9 개 월경에 몸짓을 많이 한 영아는 12 개월의 언어발달이 더 빨랐는데, 이는 몸짓의 산출이 언어발달을 예측할 수 있음을 보여주는 것이 다. 또한 Goodwyn과 Acredolo $(1993,1998)$ 에 따르면, 자녀와의 일 상 상호작용에서 의사소통적 몸짓을 사용하도록 요구한 실험집단 부모의 자녀들은 한 단어 산출이나 5 개의 상징 표현에 도달하는 속 도가 비교집단의 자녀들보다 1 개월 정도 더 빠른 것으로 나타났다. 그리고 몸짓 산출은 언어 발화의 지속적 지연을 예측하였는데, 몸 짓을 사용하여 의사소통을 하지만 말이 늦는 아동은 나중에 또래 수준만큼 언어 발화를 회복할 수 있었지만(late boomer), 몸짓을 보 이지 않았던 아동은 나중에도 지속적으로 언어발달이 지연됨을 나타내었다(Thal \& Tobias, 1992). 초기 뇌발달 연구에서도 몸짓과 관련된 운동 영역과 구어적 표상이 서로 관련되어 있음을 밝혔고 (Arbib, 2005; Bernardis \& Gentilucci, 2006), 저체중아 연구에서도 표상적 몸짓 발달에서 소근육운동발달의 중요성이 입증되었다 (Bavin et al., 2008). 이와 같이 언어발달은 운동기술의 출현 및 정 교화에 의해 영향을 받는다.

이상과 같이, 인지, 언어, 소근육운동발달은 서로 밀접한 관련성 을 가지고 영아기 지능발달에 영향을 미치므로 12 개월 이전의 인 지, 언어 및 소근육운동발달이 12 개월의 영아기 지능발달에 미치 
는 영향을 종단적으로 밝힐 필요가 있다. 이에 본 연구에서는 자기 회귀교차지연모형(autoregressive cross-lagged panel model; Cole \& Maxwell, 2003)을 적용하여 영아기 지능에 영향을 미치는 인지, 소근육운동, 언어발달 간의 종단적 관계를 살펴보고자 한다. 먼저, 자기회귀교차지연모형의 자기회귀(autoregressive)를 사용하여 각 개인의 인지, 소근육운동, 언어발달 특성이 시간의 경과에도 안정 적인지를 종단적으로 검증하고자 한다. 또한 자기회귀교차지연모 형의 교차모형(cross-lagged)을 사용하여, 인지가 언어와 소근육운 동발달에 미치는 영향뿐 아니라, 언어가 인지와 소근육운동발달 에 미치는 영향, 소근육운동이 언어와 인지에 미치는 영향을 모두 고려하는 상호적 관계, 즉 세 변인 간의 교차적 인과관계의 영향을 종단적으로 분석하고자 한다. 이는 시간 흐름에 따른 세 발달영역 간의 역동적인 상호 영향 과정을 이해할 수 있기 때문에 영유아 발 달을 통합적으로 이해하는 데 주요한 자료가 될 수 있을 것이다 (Cole \& Maxwell, 2003; Park \& Lee, 2013). 특히 본 연구에서는 자 기회귀교차지연모형을 이용한 종단매개효과 검증하고자 한다. 자 기회귀교차지연모형을 활용한 종단매개효과 검증은 독립변인, 매 개변인, 종속변인의 시간적 선행성을 고려할 수 있다는 점(Cole \& Maxwell, 2003; Park \& Lee, 2013), 매개변인과 종속변인의 이전 상 태를 통제한 상태에서 효과를 추정할 수 있다는 점에서 측정학적 으로 더 정확하다는 장점이 있다(Cole \& Maxwell, 2003; Park \& Lee, 2013). 이때 첫 번째 모형은 영아기 지능을 설명하는 기존의 주 요 흐름인 인지(비언어)발달을 중심으로 발달 경로를 살펴보고자 하며, 두 번째 모델은 최근의 주목하고 있는 언어를 포함한 인지 모 델을 중심으로 발달 경로를 살펴보되, 체화된 인지 관점에서 소근 육운동발달을 종단매개변인으로 살펴보고자 한다. 이를 위한 구체 적인 연구문제는 다음과 같다.

1. 영아의 인지와 소근육운동, 언어발달은 시간의 경과에도 안정 성을 보이는가?

2. 영아의 인지발달과 12 개월의 영아기 지능과의 관계에서 소근 육운동발달의 종단매개효과가 나타나는가?

3. 영아의 언어 및 인지발달과 12 개월의 영아기 지능과의 관계에 서 소근육운동발달의 종단매개효과가 나타나는가?

\section{연구방법}

\section{연구대상}

본 연구는 서울 및 경기 지역에 거주하는 영아와 어머니 114 명을 대상으로 영아 월령이 각각 6 개월과 9 개월, 12 개월 시점일 때 자료 를 수집하였다. Table 1 에 제시된 대로, 본 연구대상의 성별은 여아
Table 1. Characteristics of participants ( $N=114)$

\begin{tabular}{lc}
\hline \multicolumn{1}{l}{$\mathrm{N}(\%)$} \\
\hline Child \\
Female & $52(44.8)$ \\
Male & $62(55.2)$ \\
Mother & \\
Education (yr) & \\
$<12$ & $5(4.3)$ \\
$<14$ & $11(9.6)$ \\
$<16$ & $79(69.2)$ \\
$\geq 16$ & $18(15.8)$ \\
No response & $1(1.1)$ \\
Income (million KRW) & \\
$<200$ & $7(6.2)$ \\
$200-400$ & $62(54.3)$ \\
$>400$ & $45(39.5)$ \\
\hline
\end{tabular}

가 52명(44.8\%), 남아가 62명(55.2\%)이었으며, 모두 첫째 아이였다. 어머니의 교육수준은 대학교 졸업이 79명(69.2\%)으로 가장 많았고, 그 다음으로 대학원 졸업이 18 명(15.8\%)이었으며, 전문대졸도 11명 (9.6\%) 있었다. 월평균 가정의 수입은 200-400만 원이 62명(54.3\%), 400 만 원 이상이 45 명(39.5\%)였으며, 200만 원 이하가 7명(6.2\%)이 었다. 어머니의 연령은 25-30세 사이가 46명, 31-35세 사이가 61명, 36-40세 사이가 7명이었다.

\section{측정도구}

K-ASQ

영아의 인지발달, 소근육운동발달, 언어발달을 측정하기 위해서 Korean-Age and Stages Questionnaires (K-ASQ; Heo, Squires, Lee, \& Lee, 2006)의 문제해결, 소근육운동, 의사소통 영역의 자료를 사 용하였다. K-ASQ는 ASQ-II (Squires et al., 1999)의 한국형 표준화 검사도구로, 4-60개월까지의 영아의 발달을 부모의 보고로 측정한 다. K-ASQ는 의사소통, 문제해결, 소근육운동, 대근육운동, 개인사회성 등의 5 가지 영역으로 구성되어 있으며, 각 영역마다 6 문항 씩 총 30 개 문항으로 되어있다. 이 중 의사소통은 옹알이, 말하기, 듣기, 이해 등을 측정하고, 문제해결은 대상 영속성, 문제해결, 조작 능력 등을 측정하며, 소근육운동은 손과 손가락을 이용한 잡기, 쥐 기 등의 움직임을 측정한다. 영아의 월령에 따라 발달이정표를 포 함하고 있는 서로 다른 질문지를 제공받는데, 예를 들어 의사소통 의 경우 6 개월에는 당신이 보이지 않은 곳에서 아이를 부르면, 아이 는 당신의 목소리가 나는 쪽을 쳐다봅니까?”, "아이가 소리를 내면 서 놀 때, 낮거나 깊은 음으로 웅얼거립니까?”, 9개월에는 “아이에 게 몸짓으로 보여주지 않고 말로만 '빠이빠이', '짝짜궁', '깍꿍' 놀 
이를 시켰을 때 적어도 한 가지는 합니까?”, "아이가 ‘바바’, ‘다다’, '가가'와 같은 2 개의 비슷한 소리를 냅니까?” 등의 질문 내용이 포 함되어 있으며, 문제해결의 경우 6개월에는 "아이가 누워서 장난감 을 가지고 놀다가 떨어뜨리면 찾으려고 머리를 돌립니까?”, “아이 가 장난감을 바닥이나 탁자에 두드리면서 놉니까?", 9개월에는 “아 이가 작은 장난감을 2 개를 양 손에서 각각 1 개씩 집어서 1 분 정도 갖고 있습니까?”, "아이가 투명한 병 안에 있는 작은 빵조각이나 콩 크기의 과자를 건드리거나잡으려고 합니까?” 등의 질문 내용이 포 함되어 있으며, 소근육운동의 경우 6개월에는 "아이의 손에 장난 감을 쥐어주면 1 분 정도 가지고 있습니까?”, "아이가 잘 잡지 못하 더라도 엄지손가락과 다른 손가락 전체를 갈고리처럼 만들어 작은 빵 조각이나 콩 크기의 과자를 잡으려고 합니까?”, 9 개월에는 “아 이가 엄지손가락과 다른 손가락 끝으로 작은 장난감을 집습니까?”, "아이가 한두 번의 시도 후 엄지손가락과 검지손가락으로 줄을 잡 습니까?” 등의 질문 내용이 포함되어 있다. 응답은 각 문항과 관련 된 행동을 보이는 정도에 따라 '예(행동을 수행할 때)', '가끔(행동 을 보이기 시작할 때)', 그리고 '아니오(아직 행동을 수행하지 못할 때)' 중 하나를 하도록 되어있다. 각 문항에 대한 응답 중 '예'는 10 점, '가끔'은 5 점, '아니오'는 0 점으로 환산된다. 본 연구자료에서는 의사소통, 문제해결, 소근육운동의 환산점수 평균을 사용하였다. K-ASQ는 K-DDST, DIAL-3, K-BSDI-II, K-WPPSI와 유의미한 상 관이 있는 것으로 보고되었다(Chung et al., 2014). 본 연구의 신뢰 도 계수(Cronbach $\alpha$ )를 살펴보면, 6 개월(t1)의 의사소통, 문제해결, 소근육운동발달의 신뢰도 계수는 각각 $.40, .31, .45$ 이었으며, 9 개월 (t2)의 의사소통, 문제해결, 소근육운동발달의 신뢰도 계수는 각각 $.56, .57, .44$ 였다.

\section{한국형베일리영유아발달검사 2판(K-BSID-II)}

본 연구에서는 12 개월의 영아기 지능(mental ability)을 측정하기 위하여 선행연구(Molfese \& Acheson, 1997; Reznick et al., 1997)와 동일하게 베일리영유아발달검사 2판 한국판(Korean version of Bayley Scales of Infant Development-II, K-BSID-II: Park \& Cho, 2006) 정신(mental)척도를 사용하였다. K-BSID-II는 BSID-II (Bayley, 1993)의 한국형 표준화 검사도구로, K-BSID-II는 정신척도, 운 동(motor)척도, 행동평정척도로 구성되어 있다. K-BSID-II의 정신 척도는 일반적으로 지적 능력이라고 고려되는 활동들(예: 사고, 기 억, 문제해결, 범주화, 언어 등의 정신능력)을 측정하기에, 영아기 지 적 능력 평가를 위해 전 세계적으로 가장 많이 사용되는 도구이다 (Dezoete, MacArthur, \& Tuck, 2003; Siegel, 1983). K-BSID-II는 1 개월에서 42 개월을 대상으로 하며, 실시의 효율성을 위해 해당 월
령마다 문항세트가 제시되어 있어서 해당 월령의 문항세트의 시작 점(기저선)에서 중지점(문항세트 끝문항)까지의 문항을 실시한다. 본 연구에서는 정신척도 12 개월 문항 세트를 실시하였고, 통과한 문항수로 원점수를 산출한 후 해당 월령의 규준표를 이용하여 정 신발달지수(MDI)로 환산하였다. 정신발달지수는 평균 100점, 표 준편차 15점인 정상분포 규준을 토대로 변환한 점수로, 점수의 범 위는 40 점에서 160 점이다. 본 연구에서의 정신척도 신뢰도 계수는 .61이었다.

\section{연구절차}

본 연구는 수도권에 거주하는 영아와 어머니를 대상으로 2015년 1월부터 3월까지 1차 자료수집을 하였고, 2015년 4월부터 6월까지 2차 자료 수집을 실시하였으며, 2015년 7월부터 9월까지 3차 자료 수집을 하였다. 본 연구의 참여자는 대학부설 연구소에서 실시하 는 방문부모교육대상자로 홈페이지 온라인 접수를 통해 양육전문 가가 가정에 방문하여 양육코칭 해주는 것을 신청한 가정의 자녀 들이다. 양육전문가는 유아교육학, 간호학, 교육학 등을 전공하고 소정의 연수과정을 이수한 사람들로서 각 가정을 방문해 아기의 발달상태를 간단히 확인하고 양육코칭을 해드렸다. 양육전문가는 영아기 자녀가 6 개월, 9 개월 되는 시점에 가정을 방문하여 어머니 와 함께 자녀의 K-ASQ검사를 실시하였다. 3 차 자료수집은 1 차와 2 차 자료수집 대상 중 참여를 원하는 경우에만 대학부설 연구소로 방문하여 K-BSID-II를 실시하였다. 자료수집 시 참여 어머니에게 는 연구목적과 절차를 설명하고 연구참여 의사를 밝힌 경우에만 동의서를 받아 연구에 참여하도록 하였다. 연구참여에 동의한 어머 니와 영아 116 쌍의 자료 중에서 3 차의 K-BSID-II 검사에 응하지 않 은 2 쌍의 자료를 제외하여 최종적으로 114 쌍의 자료를 분석하였다.

\section{자료분석}

영아의 인지, 소근육운동, 언어가 12 개월의 영아기 지능에 미치 는 종단적 매개효과를 검증하기 위하여 자기회귀교차지연모형을 사용하였다. 자기회귀 교차지연모형 검증은 특정 시점 $(\mathrm{t})$ 의 값이 이 전 시점(t-1)의 값에 의해 설명되는 자기회귀모형(autoregressive modeling)을 다변량모형으로 확장시켜 두 변인 간의 상호지연효과 (cross-lagged effect)를 추정할 수 있도록 한 모형이다(Kim, Kim, \& Hong, 2009). 자기회귀교차지연모형을 이용하면 시간적 인과성에 따라 독립변인, 매개변인, 종속변인을 고려할 수 있으며, 매개변인 과 종속변인의 이전 상태를 통제한 상태에서 관련성을 살펴볼 수 있다는 장점이 있다(Cole \& Maxwell, 2003; Park \& Lee, 2013). 모형 검증에 앞서, 각 측정변인들이 정규분포를 이루고 있는지 확인하기 
위하여 왜도, 첨도를 점검하였으며, 측정변인들 간의 상호관련성을 알아보기 위하여 Pearson의 적률상관계수를 산출하였다. 이후 연 구모형이 설정되면 내재된 경쟁모형과의 비교를 통해 간명하면서 도 설명력이 있는 최적의 모형을 선택하였고, 최종모형의 자기회귀 계수와 교차지연계수를 통해 변인 간의 인과적 관계를 검증하였다 (Hong, 2016). 모형비교를 할 때는 차이 검증과 적합도 지수를 모두 고려하여, 차이 검증을 위해서는 $\chi^{2}$ 검정을, 적합도지수로 TLI, CFI, RMSEA를 이용하였다. TLI, CFI는 상대적인 지수로 .90 이상이면 좋은 적합도로, RMSEA는 절대적합도로 .05 이하이면 좋은 적합 도, .08 이하이면 적절한 적합도로 해석하였다(Browne \& Cudeck, 1993). 최종모델의 간접효과를 확인하기 위해 부트스트래핑(bootstrapping) 실시하였고 유의수준 .05 수준에서 통계적 유의성을 검 증하였다. 본 연구의 데이터는 SPSS 23.0과 AMOS 23.0 을 이용하 여 분석하였다.

\section{연구모형}

자기회귀교차모형을 이용하여 종단적 매개효과를 검증하기 위

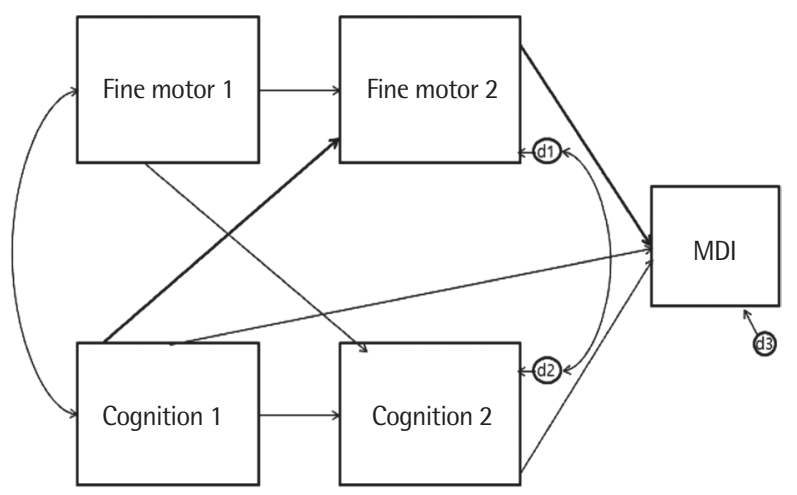

Figure 1. Model 1.

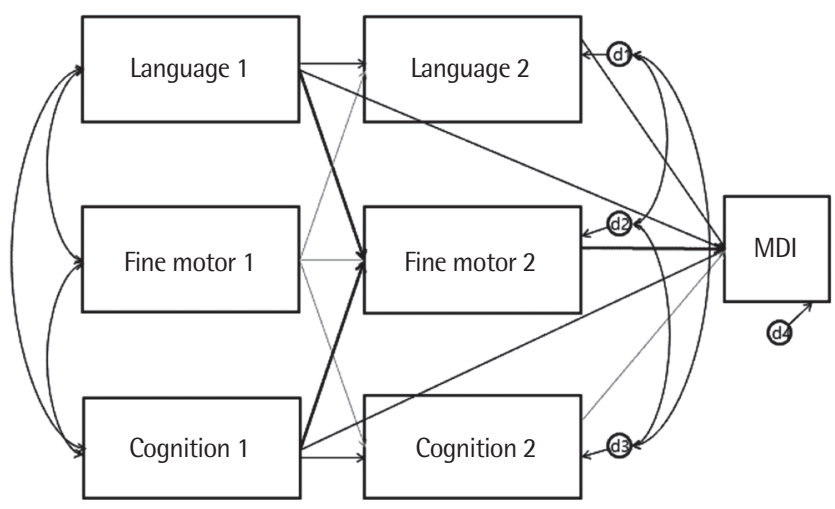

Figure 2. Model 2.
한 모형은 Figures 1,2와 같다. 연구모형1을 통해서는 6개월의 인지 발달 $(\mathrm{t} 1)$ 이 9 개월의 소근육운동발달 $(\mathrm{t} 2)$ 을 매개로 하여 12 개월의 영아기 지능에 영향을 미치는지 살펴보았다. 연구모형2는 모형1에 언어를 추가로 투입하여 6 개월의 언어발달(t1)이 9 개월의 소근육 운동발달(t2)을 매개로 하여 12 개월의 영아기 지능에 영향을 미치 는지 살펴보았다.

\section{연구결과}

\section{기술통계}

본 연구에서는 영아의 인지, 소근육운동, 언어발달이 시간의 흐 름에 따라 어떻게 변화하여 12 개월의 영아기 지능을 예측하는지 살펴보았다. 각 시점(t)에서 측정한 변인들의 변화를 알아보기 위하 여, Table 2에 제시된 것처럼 t1 (6개월)과 t2 (9개월)에 측정한 인지 와 소근육운동, 언어발달의 평균과 표준편차를 구하였고, 시점3 (12개월)에 측정한 영아기 지능의 평균, 표준편차를 구하였다. 또한 모형 검증에 앞서 정규성 가정이 충족되는지 확인하기 위하여 각 각의 왜도와 첨도를 확인하였다. 왜도의 절대값이 2 보다 작고, 첨도 의 절대값이 7보다작은 경우에는 추정에 영향을 주지 않는데(Kline, 2005), 본 연구에서는 왜도가 2 보다 작고, 첨도가 4 보다 작았기 때 문에 다변량 정규분포 가정을 충족하였다.

\section{연구변인들의 상관분석}

경로분석에 앞서서 측정시점별로 상관관계를 분석을 실시하였 다. 시점1 (6개월)과 시점2 (9개월)에 측정한 인지와 소근육운동, 언 어 발달과 시점3 (12개월)에 측정한 영아기 지능 간에 관련성을 알

Table 2. Mean, standard deviation, skewness, \& kurtosis of COG, FM, LAN, and MDI

\begin{tabular}{lcccc}
\hline & Mean & SD & Skew & Kurtosis \\
\hline COG_t1 & 8.427 & 1.309 & -.586 & -.068 \\
COG_t2 & 8.491 & 1.566 & -1.585 & 3.549 \\
FM_t1 & 8.053 & 1.677 & -.973 & .638 \\
FM_t2 & 8.614 & 1.688 & -1.741 & 3.958 \\
LAN_t1 & 8.125 & 1.314 & -.485 & -.292 \\
LAN_t2 & 6.358 & 2.161 & -.207 & -.698 \\
MDI_t3 & 88.69 & 13.77 & -.062 & .443 \\
\hline
\end{tabular}

$\mathrm{COG}=$ cognition; $\mathrm{FM}=$ fine motor; $\mathrm{LAN}=$ language; $\mathrm{MDI}=$ mental development in dex; $\mathrm{t}=$ measurement point; $\mathrm{t} 1$ = language, cognitive and fine motor development at 6 months; $\mathrm{t} 2$ = language, cognitive and fine motor development at 9 months; $\mathrm{t} 3=$ mental ability at 12 months.

COG, FM, and LAN are examined using Korean-Age and Stages Questionnaires (Heo, Squires, Lee, \& Yi, 2006), MDI using Korean version of Bayley Scales of Infant Development II (Park \& Cho, 2006). 
아보았고 그 결과는 Table 3과 같다. 상관이 높은 측정치는 인지 $(\mathrm{COG})$ 및 언어 $(\mathrm{LAN})$ 각각의 시점1과 시점2의 상관(안정성)을 측 정할 때이며, 시점1에서의 인지(COG1)와 소근육운동(FM1) 간의 상관을 측정할 때, 시점 1 의 인지(COG1)와 시점2의 소근육운동 (FM2)간의 교차지연 상관을측정할 때, 그리고시점2의 인지(COG2), 소근육운동(FM2), 언어(LAN2)와 시점3의 영아기 지능(MDI) 간 의 상관을 측정할 때였다.

\section{인지와 영아기 지능 관계에서 소근육운동발달의 종단매개효과 검증}

영아의 인지와 영아기 지능 간의 관계에서 소근육운동발달의 종 단매개효과를 살펴보기 위하여 Figure 1과 같이 모형을 설정하고 경로계수를 추정하였다.

그 결과, 6 개월의 인지는 12 개월의 영아기 지능에 미치는 직접효 과가 통계적으로 유의미하지 않은 것으로 나타났다. 이에 직접효과 를 0 으로 고정한 완전매개모형(더 간명한 모형)과 부분매개모형(더 복잡한 모형) 중 어느 모형이 더 적절한지 확인하기 위하여 $\chi^{2}$ 차이 검증을 실시하였다. 그 결과, $\chi^{2}=.66$ 으로 나타나 더 간명한 모형을 최종모형으로 결정하였다 $(p=.42)$. 최종 선택된 완전매개모형의 적 합도는 Table 4 에 제시된 것처럼 $\chi^{2}(2, \mathrm{~N}=114)=2.18, p=.34, \mathrm{CFI}=.99$, $\mathrm{TLI}=.99, \mathrm{RMSEA}=.03$ 으로 적합한 것으로 나타났으며, 경로계수 추정결과는 Figure 3에 제시하였다.

먼저, 연구문제 1 인 인지발달과 소근육운동발달이 시간이 경과 해도 안정적으로 유지되는지 살펴보았다. Table 5 에 제시되어 있듯 이, 6 개월의 인지는 9 개월의 인지에 미치는 영향이 통계적으로 유

Table 3. Correlation of longitudinal data of COG, FM, LAN, and MDI ( $N=114)$

\begin{tabular}{llllllll}
\hline & COG_t1 & COG_t2 & FM_t1 & FM_t2 & LAN_t1 & LAN_t2 & MDI_t3 \\
\hline COG_t1 & 1.00 & & & & & & \\
COG_t2 & $0.46^{* * *}$ & 1.00 & & & & & \\
FM_t1 & $0.31^{* * *}$ & 0.16 & 1.00 & & & & \\
FM_t2 & $0.35^{* * *}$ & $0.36^{* * *}$ & $0.23^{* *}$ & 1.00 & & & \\
LAN_t1 & 0.17 & 0.16 & 0.10 & $0.26^{*}$ & 1.00 & & \\
LAN_t2 & 0.04 & $0.20^{*}$ & 0.16 & 0.13 & $0.32^{* * *}$ & 1.00 & \\
MDI_t3 & 0.14 & $0.30^{* * *}$ & $0.19^{*}$ & $0.38^{* * *}$ & 0.03 & $0.32^{* * *}$ & 1.00 \\
\hline
\end{tabular}

$\mathrm{COG}=$ cognition; $F \mathrm{M}=$ fine motor; $\mathrm{LAN}=$ language; $\mathrm{MDI}=$ mental development index; $\mathrm{t}=$ measurement point; $\mathrm{t} 1$ = language, cognitive and fine motor development at 6 months; $\mathrm{t} 2=$ language, cognitive and fine motor development at 9 months. ${ }^{*} p<.05,{ }^{* *} p<.01,{ }^{* * *} p<.001$.

Table 4. Goodness-of-fit of the final model $(\mathrm{N}=114)$

\begin{tabular}{lccccc}
\hline$\chi^{2}$ & $p$-value & $d f$ & $\mathrm{CFI}$ & TLI & RMSEA \\
\hline 2.18 & .34 & 2 & .99 & .99 & .03 \\
\hline
\end{tabular}

의미한 것으로 나타났으나 $(\beta=.563, p<.001), 6$ 개월의 소근육운동 은 9 개월의 소근육운동에 미치는 영향이 유의미하지 않는 것으로 나타났다 $(\beta=.141, p>.05)$. 즉, 6 개월의 인지발달은 시간의 변화에 도 불구하고 9 개월의 인지발달을 안정적으로 예측하나, 6 개월의 소근육운동발달은 9 개월의 소근육운동발달을 안정적으로 예측 하지 못하였다.

이후 연구문제 2 인 소근육운동의 종단매개효과를 검증하기 위하 여 부트스트래핑 방법을 사용하였다(Shrout \& Bolger, 2002). Table 6 에 제시되어 있듯이 6개월의 인지발달은 9개월의 소근육운동발 달을 매개로 12 개월의 영아기 지능에 미치는 매개효과가 $95 \%$ 신뢰 구간에서 통계적으로 유의미한 것으로 확인되었다. 즉 6 개월의 소 근육운동발달이 통제된 상태에서, 6 개월의 인지발달은 9 개월의 소 근육운동발달을 매개로 하여 12 개월의 영아기 지능을 유의미하게 예측하였다.

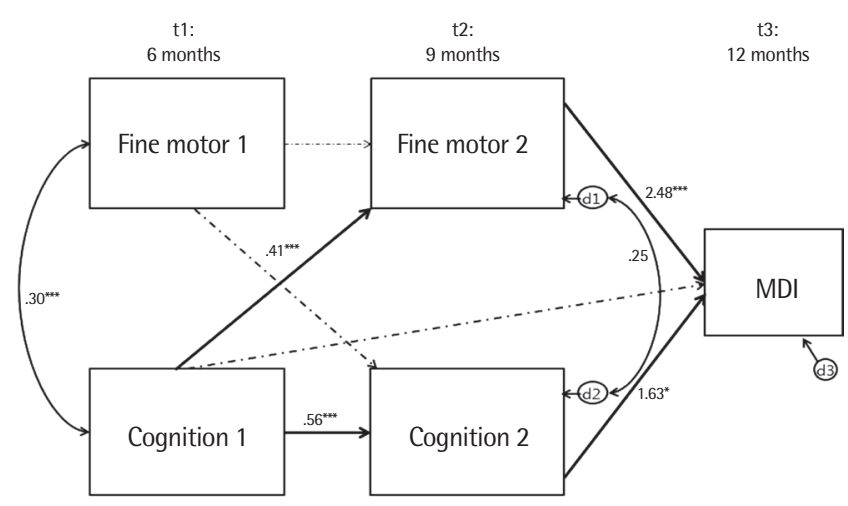

Figure 3. Path model testing the interrelations between and predictive power of fine motor and cognition among each other and on mental developmental index (MDI).

$\mathrm{t}=$ measurement point; $\mathrm{t} 1$ = language, cognitive and fine motor development at 6 months; t2 = language, cognitive and fine motor development at 9 months; $\mathrm{t} 3=$ mental ability at 12 months. ${ }^{*} p<.05,{ }^{* * *} p<.001$.

Table 5. Longitudinal mediation statistics of model1 $(\mathrm{N}=114)$

\begin{tabular}{lccc}
\hline & \multicolumn{1}{c}{ B } & SE & $\beta$ \\
\hline COG_t1 $\rightarrow$ COG_t2 auto-regressive coefficient & $.563^{* * *}$ & .103 & .471 \\
FM_t1 $\rightarrow$ FM_t2 auto-regressive coefficient & .141 & .092 & .139 \\
COG_t1 $\rightarrow$ FM_t2 cross-lagged coefficient & $.405^{* * *}$ & .118 & .312 \\
FM_t1 $\rightarrow$ COG_t2 cross-lagged coefficient & .043 & .080 & .046 \\
COG_t2 $\rightarrow$ MDI cross-lagged coefficient & $1.625^{*}$ & .815 & .185 \\
FM_t2 $\rightarrow$ MDI_t3 cross-lagged coefficient & $2.476^{* * *}$ & .750 & .305
\end{tabular}

$\mathrm{COG}=$ cognition; $\mathrm{FM}=$ fine motor; $\mathrm{LAN}=$ language; $\mathrm{MDI}=$ mental development index; $\mathrm{t}=$ measurement point; $\mathrm{t} 1$ = language, cognitive and fine motor development at 6 months; $\mathrm{t} 2=$ language, cognitive and fine motor development at 9 months; $\mathrm{t} 3=$ mental ability at 12 months.

${ }^{*} p<.05,{ }^{* * *} p<.001$ 
Table 6. Test of longitudinal mediation for fine motor development at 9 months on MDI at 12 months

\begin{tabular}{lccc}
\hline longitudinal mediation PATH & B & SE & $p$-value \\
\hline COG_t1 $\rightarrow$ FM_t2 $\rightarrow$ MDI_t3 & 1.917 & .745 & .005 \\
\hline
\end{tabular}

$\mathrm{COG}=$ cognition; $\mathrm{FM}=$ fine motor; $\mathrm{LAN}=$ language; $\mathrm{MDI}=$ mental development index; $\mathrm{t}=$ measurement point; $\mathrm{t} 1$ = language, cognitive and fine motor development at 6 months; $\mathrm{t} 2=$ language, cognitive and fine motor development at 9 months; $\mathrm{t} 3=$ mental ability at 12 months.

Table 7. Goodness-of-fit of the final model

\begin{tabular}{lccccc}
\hline$\chi^{2}$ & $p$-value & $d f$ & CFI & TLI & RMSEA \\
\hline 3.37 & .40 & 4 & 1.00 & 1.03 & .00 \\
\hline
\end{tabular}

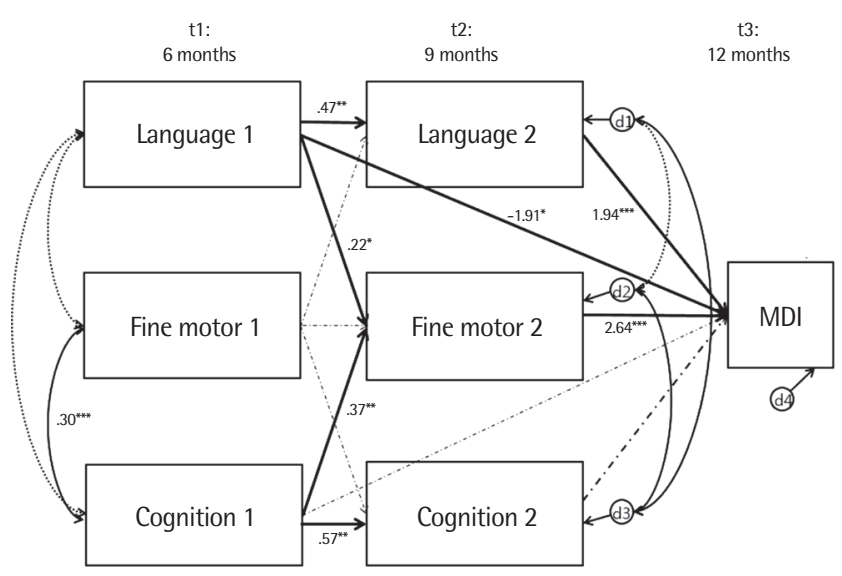

Figure 4. Path model testing the interrelations between and predictive power of language, fine motor, and and cognition among each other and on mental developmental index (MDI).

$\mathrm{t}=$ measurement point; $\mathrm{t} 1$ = language, cognitive and fine motor development at 6 months; t2 = language, cognitive and fine motor development at 9 months; $\mathrm{t} 3=$ mental ability at 12 months. ${ }^{*} p<.05,{ }^{* *} p<.01,{ }^{* * *} p<.001$.

\section{언어 및 인지와 영아기 지능 관계에서 소근육운동발달의 종단매개효과 검증}

기존의 모형에 언어를 추가하여, 영아의 언어 및 인지가 영아기 지능에 미치는 영향에서 소근육운동발달의 종단매개효과를 살펴 보기 위하여 Figure 2와 같이 모형을 설정하고 경로계수를 추정하 였다.

그 결과, 모형 1 과 동일하게 6 개월의 인지는 12 개월의 영아기 지능 에 미치는 직접효과가 통계적으로 유의미하지 않은 것으로 나타났 으나, 6 개월의 언어는 12 개월의 영아기 지능에 미치는 직접효과가 유의미한 것으로 나타났다. 이에 인지의 직접효과만을 0 으로 고정 한 부분매개모형(더 복잡한 모형)과 인지와 언어의 직접효과를 모 두 0 으로 고정한 완전매개모형(더 간명한 모형) 중 어떤 모형이 더 적합한지 확인하기 위하여 $\chi^{2}$ 차이검증을 실시하였다. 그 결과, $\chi^{2}=$
Table 8. Longitudinal mediation statistics of model 2

\begin{tabular}{llll}
\hline & \multicolumn{1}{c}{ B } & SE & $\beta$ \\
\hline LAN_t1 $\rightarrow$ LAN_t2 auto-regressive coefficient & $.468^{* *}$ & .144 & .285 \\
FM_t1 $\rightarrow$ FM_t2 auto-regressive coefficient & .133 & .090 & .132 \\
COG_t1 $\rightarrow$ COG_t2 auto-regressive coefficient & $.576^{* * *}$ & .101 & .479 \\
COG_t1 $\rightarrow$ FM_t2 cross-lagged coefficient & $.378^{* *}$ & .117 & .292 \\
LAN_t1 $\rightarrow$ FM_t2 cross-lagged coefficient & $.219^{*}$ & .109 & .169 \\
FM_t1 $\rightarrow$ LAN_t2 cross-lagged coefficient & .166 & .114 & .130 \\
FM_t1 $\rightarrow$ COG_t2 cross-lagged coefficient & .040 & .080 & .043 \\
LAN_t2 $\rightarrow$ MDI cross-lagged coefficient & $1.942^{* * *}$ & .555 & .301 \\
FM_t2 $\rightarrow$ MDI cross-lagged coefficient & $2.644^{* * *}$ & .723 & .323 \\
COG_t2 $\rightarrow$ MDI_t3 cross-lagged coefficient & 1.278 & .774 & .145 \\
LAN_t1 $\rightarrow$ MDI cross-lagged coefficient & $-1.905^{*}$ & .912 & -.180
\end{tabular}

$\mathrm{COG}=$ cognition; $\mathrm{FM}=$ fine motor; $\mathrm{LAN}=$ language; $\mathrm{MDI}=$ mental development index; $\mathrm{t}=$ measurement point; $\mathrm{t} 1$ = language, cognitive and fine motor development at 6 months; t2 = language, cognitive and fine motor development at 9 months; $\mathrm{t} 3=$ mental ability at 12 months.

${ }^{*} p<.05,{ }^{* *} p<0.01,{ }^{* * *} p<.001$.

Table 9. Test of longitudinal mediation for fine motor development at 9 months on $\mathrm{MDI}$ at 12 months

\begin{tabular}{lccc}
\hline longitudinal mediation PATH & B & SE & $p$-value \\
\hline COG_t1 $\rightarrow$ FM_t2 $\rightarrow$ MDI_t3 & 1.735 & .693 & .002 \\
LAN_t1 $\rightarrow$ FM_t2 $\rightarrow$ MDI_t3 & 1.490 & .551 & .001 \\
\hline
\end{tabular}

$\mathrm{COG}=$ cognition; $F M=$ fine motor; $\mathrm{LAN}=$ language; $\mathrm{MDI}=$ mental development index; $\mathrm{t}=$ measurement point; $\mathrm{t} 1$ = language, cognitive and fine motor development at 6 months; t2= language, cognitive and fine motor development at 9 months; $\mathrm{t} 3=$ mental ability at 12 months.

4.16으로 나타나 더 복잡한 모형인 부분매개모형을 최종모형으로 결정하였다 $(p=.041)$. 최종 선택된 부분매개모형의 적합도는 Table 7 에 제시된 것처럼 $\chi^{2}(4, \mathrm{~N}=114)=3.37, p=.40, \mathrm{CFI}=1.00, \mathrm{TLI}=1.03$, $\mathrm{RMSEA}=.00$ 으로 적합한 것으로 나타났으며, 경로계수 추정결과 는 Figure 4 에 제시하였다

먼저, 연구문제 1 인 언어와 인지, 소근육운동발달의 안정성을 살 펴보았다. Table 8 에 제시된 것처럼, 언어를 추가한 모형2에서도 6 개 월의 인지는 9 개월의 인지에 미치는 영향도 통계적으로 유의미한 것으로 나타났으며 $(\beta=.576, p<.001), 6$ 개월의 언어도 9 개월의 언어 에 미치는 영향이 통계적으로 유의미한 것으로 나타났다 $(\beta=.468$, $p<.01)$. 그러나 모형 2 에서도 6 개월의 소근육운동은 9 개월의 소근 육운동에 미치는 영향이 유의미하지 않는 것으로 나타났다 $(\beta=.133$, $p>.05)$. 즉, 6 개월의 인지발달과 언어발달은 시간의 변화에도 불구 하고 9 개월의 인지발달과 언어발달을 안정적으로 예측하나, 6 개월 의 소근육운동발달은 9 개월의 소근육운동발달을 안정적으로 예 측하지 못하였다.

이후 연구문제 2 인 언어, 인지, 소근육운동과 영아기 지능 간의 
종단매개효과를 검증하기 위하여 부트스트래핑 방법을 사용하였 다. Table 9에 제시되어 있듯이, 모형1과 동일하게 6개월의 인지발달 은 9 개월의 소근육운동발달을 매개로 하여 12 개월의 영아기 지능 에 미치는 효과가 통계적으로 유의미한 것 이외에도, 모형2에서는 6 개월의 언어발달이 9 개월의 소근육운동발달을 매개로 하여 12 개 월의 영아기 지능에 미치는 매개효과가 통계적으로 유의미하였다. 즉, 6 개월의 소근육운동발달이 통제된 상태에서 6 개월의 인지발달 은 9 개월의 소근육운동발달을 매개로 하여 12 개월의 영아기 지능 을 유의미하게 예측한 것 이외에도, 6 개월의 소근육운동 발달을 통 제했을 때 6 개월의 언어는 9 개월의 소근육운동발달을 매개로 하 여 12 개월의 영아기 지능을 유의미하게 예측하였다. 한편, 모형1에 언어가 추가되니 9 개월의 인지가 12 개월의 영아기 지능을 더 이상 유의미하게 예측하지 못하였다.

\section{논의 및 결론}

본 연구는 12 개월 영아기 지능에 영향을 미치는 인지발달, 언어 발달, 소근육운동발달 간의 종단적 관계를 살펴보고자 하였다. 이 를 위해 114 명의 영아를 대상으로, 6 개월과 9 개월에는 K-ASQ를 통 해 영아의 언어, 인지, 소근육운동발달을 각각 측정하였으며, 12 개 월에는 K-BSIS-II를 통해 영아기 지능을 측정하였다.

본 연구의 결과 및 그에 따른 논의점을 살펴보면 다음과 같다.

첫째, 영아의 언어발달과 인지발달이 시간 경과에도 안정성이 유 지되는지 살펴본 결과, 6 개월의 언어발달과 인지발달은 각각 9 개월 의 언어발달과 인지발달에 유의미하게 영향을 미치며 시간 경과에 따른 안정적인 특성을 보였다. 본 연구에서 밝혀진 영아기 언어발달 의 안정성은 10 개월에서 16 개월의 언어발달의 안정성을 연구한 Thal과 Katich (1996)의 연구와 일치하는 결과이며, 국내 영유아를 대상으로 8 개월에서 18 개월의 어휘발달의 안정성을 연구한 Lee와 Chang (2005)의 연구와 일치하는 결과이다. 대체로 언어발달의 불 안정성은 12 개월 이후의 아동들에게서 보고된다는 점을 감안할 때(Bates, Dale, \& Thal, 1995; McCall, Eichorn, \& Hogatry, 1977; Reznick \& Goldsmith, 1989), 본 연구에서 보고된 안정성은 12개월 이전시기의 영아를 대상으로 한 선행연구를 반복 검증하는 결과이 다. 한편, 본 연구에서 밝혀진 또 다른 결과인 영아기 인지발달의 안 정성은 7 개월과 12 개월간의 주의, 속도, 재인 기억의 안정성을 보고 한 Rose 등(2004)의 연구결과와 일치하는 결과이다. 더 나아가, Rose 등(2004)의 연구는 '주의', ‘속도'와 같은 정보처리 과제로 구성된 실 험을 통해 영아 인지발달의 안정성을 살펴보았다면, 본 연구는 '문 제해결, '대상 영속성'이 포함된 다면적 문항으로 구성된 발달검사
를 통해 인지발달의 안정성을 알아보았다는 데 의의를 지닌다.

둘째, 영아의 인지발달이 12 개월의 영아기 지능에 미치는 영향 을 소근육운동발달이 종단적으로 매개하는지 확인한 결과, 종단 적 완전매개모형이 확인되었다. 6 개월의 인지발달은 12 개월의 영아 기 지능에 직접적인 영향을 주기보다는 9 개월의 소근육운동발달 을 매개로 하여 간접적인 영향을 미쳤다. 이는 체화된 인지 관점을 지지하는 결과로서, 인지능력이 영아기 지능을 설명하는 데 있어서 소근육운동기술의 발달이 중요한 역할을 함을 의미한다. 즉, 9 개월 의 잡는 기술의 변화는 환경을 탐색하고 상호작용하는 영아의 행 위를 변화시키면서 환경에 적응하는 능력으로서의 지능발달에도 영향을 미쳤음을 알 수 있다. 이러한 결과는 운동발달이 이후 발달 의 매개변수로 작용했다는 Bushnell과 Boudreau (1993)의 연구와 일치하는 결과이며, 운동기술의 발달이 대상을 조작하고 탐색하는 방식의 변화를 가져온다는 선행연구와도 일치하는 결과이다(Kotwica, Ferre, \& Michel, 2008; Soska, Adolph, \& Johnson, 2010; Thelen \& Corbetta, 1994). 이는 영아기 지능발달을 위한 교육적 개입을 할 때, 영아 손에 물건을 쥐어준 상태에서 인지적 조작을 도와주는 개입을 하기 보다는 영아가 스스로 주변 사물을 탐색하면서 관심 있는 사물을 집어보는 경험부터 시작하는 것이 더욱 효과적임을 시사한다.

셋째, 영아의 인지발달 및 언어발달이 12 개월의 영아기 지능에 미치는 영향에서 소근육운동발달이 유의미한 종단매개효과를 나 타내는지 확인한 결과, 종단적 부분매개모형이 확인되었다. 즉, 6 개 월의 언어발달은 9 개월의 소근육운동발달을 매개로 하여 12 개월 의 영아기 지능에 간접적인 영향을 미치는 것으로 나타났다. 이는 체화된 언어 관점을 지지하는 연구결과로서, 팔과 손의 움직임을 더욱 잘 통제할 수 있다는 것은 체화된 언어인 몸짓의 발달에 영향 을 미치게 되고(Iverson, 2010; Iverson \& Thelen, 1999; Parladé \& Iverson, 2011), 몸짓을 포함한 소근육운동발달의 정교화는 12 개월 의 영아기 지능에 영향을 미친다는 선행연구 결과를 지지하는 결 과이다(Wijnroks \& van Veldhoven, 2003). 이전의 연구가 극소저 체중아와 언어지체집단을 대상으로 하여 언어, 운동, 인지 간의 관 련성을 살펴보았다면(Bavin et al., 2008; Caselli, Rinaldi, Stefanini, \& Volterra, 2012; Lee, 2011), 본 연구결과는 정상 영아를 대상으로 이들 변인들 간의 종단적 매개효과를 검증하였다는 데 의의를 지 닌다. 한편, 모델2에서는 6 개월의 언어발달이 12 개월의 영아기 지 능을 직접적으로 예측했을 뿐 아니라 모델1에서 유의미했던 경로 인 9 개월의 인지발달에서 12 개월의 영아기 지능으로 가는 경로의 유의미성이 사라지는 결과가 나타났다. 이는 12 개월의 영아기 지능 발달에 있어서 6 개월의 언어발달이 중요한 역할을 함을 의미한다. 
이 결과는 7 개월의 표상적 유능성 차원이 11 세의 아동기 지능에 영 향을 미친다는 Rose 등(2012)의 연구와 유사한 결과로서, 지능에 영향을 미치는 주요 변인으로서의 언어 연구가 영아기부터 시작되 어야 함을 시사한다. 최근에 베일리영유아발달검사 3 판에서는 언 어척도를 별개의 하위검사로 세분화하였는데, 이는 매우 어린 영아 기부터 비언어적 인지능력과 구분되는 언어성 능력에 대한 별도의 정보가 지능 연구에서 주요하게 다루어져야 함을 의미한다(Lee,

Bang, \& Lee, 2009; Lee, Kim, Bang, \& Lee, 2014).

본 연구의 결과를 종합하면, 6 개월의 언어와 인지발달은 각각 9 개월의 언어와 인지발달을 유의미하게 영향을 미치며 시간 경과에 따른 안정적인 특성을 보였으며, 6 개월의 인지발달은 9 개월의 소근 육운동발달을 매개로 하여 12 개월의 영아기 지능을 유의미하게 예 측하였고, 6 개월의 언어발달은 9 개월의 소근육운동발달을 매개로 하여 12 개월의 영아기 지능을 유의미하게 예측하였다. 본 연구는 자기회귀교차지연모형을 활용한 종단매개효과 검증을 통하여 독 립변인, 매개변인, 종속변인의 시간적 선행성을 고려할 수 있다는 점, 매개변인과 종속변인의 이전 상태를 통제한 상태에서 효과를 추정할 수 있다는 점에서 측정학적으로 더 정확하다는 장점이 있 다. 또한 본 연구결과는 언어발달을 인지발달 및 소근육운동발달 과의 역동적인 관계에서 상호영향 과정을 살펴보아 영아기 지능발 달 경로를 통합적으로 이해할 수 있는 기초 자료가 될 것이다. 이와 더불어, 소근육운동발달을 매개로 영아기 지능에 미치는 영향을 밝힘으로써 체화된 언어발달 연구를 위한 주요 자료가 될 수 있으 며, 영아기 지능 연구에서 언어발달의 중요성을 시사하는 자료가 될수 있다.

이와 같은 연구의 의의에도 불구하고 본 연구의 제한점 및 추후 연구를 위한 제안은 다음과 같다. 먼저, 본 연구는 발달이 급변하는 시기인 생후 6-12개월의 인지와 언어, 운동영역의 발달을 측정하기 에 3 개월 간격으로 3 차 검사가 이루어졌다. 그러나 검사 수행의 안 정성에 대한 선행연구(McCall, 1983; Miller, 1987)에서 두 검사 간 간격이 짧을수록 안정성이 증가한다고 보고하고 있어서, 본 연구에 서 밝혀진 안정성이 단기간 간격으로 인해 나타났을 수 있다. 추후 연구에서는 인지, 언어, 소근육운동발달 간의 종단적인 관계성을 유아기까지 지속적으로 추적하는 연구를 제안한다. 둘째, 본 연구 에서는 발달검사인 K-ASQ를 통해 6개월과 9 개월의 인지, 언어, 소 근육운동발달을 측정하였는데, 이는 각 개월마다 6문항으로 구성 되어 있어서 각 영역의 발달을 온전히 측정하는 데 제한이 있을 수 있다. 영아기의 새로운 발달 특성 출현은 유기적으로 움직이는 발 달에 영향을 미칠 수 있다. 예를 들어 18-24개월의 어휘폭발기의 출 현은 인지 및 소근육운동발달과의 종단적 관계가 본 연구의 결과
와는 다른 경로로 나타날 수 있다. 추후 연구에서는 주요 발달이정 표를 중심으로 한 관찰법 및 실험법과 같은 다양한 측정방법을 적 용한 종단 연구를 제안한다. 셋째, 본 연구에서 설정한 모형의 경우 적합도 지수가 모두 타당하게 나타났다. 이러한 모형이 영아의 언 어, 인지, 소근육, 지능과의 관계의 시간적 변화를 설명하는 유일한 모형은 아니다. 본 연구에서는 소근육발달을 중심으로 살펴보았으 나 영아의 지능과 관련된 다른 변인들을 적용한 모형을 검증하는 추후 연구가 진행될 필요가 있다. 또한 본 연구는 언어, 인지, 소근 육, 지능과의 발달적 경향을 종단연구 설계로 입증하였다. 하지만 실제 가정이나 기관에서 영아의 발달을 증진시킬 수 있는 교육프 로그램이나 교재교구에 노출이 이루어지고 있으며, 이러한 교육적 영향을 입증하기에는 제한점이 있다. 마지막으로 본 연구의 자료는 서울과 경기지역에서만 수집되었으므로 연구에서 얻어진 결과를 일반화하는 데 제한점이 있다. 따라서 본 연구결과를 일반화하기 위해 광범위한 지역에서 표집된 영아들을 대상으로 한 연구가 진행 될 필요가 있다.

\section{REFERENCES}

Abbot-Smith, K., \& Tomasello, M. (2006). Exemplar-learning and schematization in a usage-based account of syntactic acquisition. The Linguistic Review, 23, 275-290.

Arbib, M. A. (2005). From monkey-like action recognition to human language: an evolutionary framework for neurolinguistics. Behavioral and Brain Science, 28, 105-167.

Bates, E., Benigni, L., Bretherton, I., Camaioni, L., \& Volterra, V. (1979). The emergence of symbols: cognition and communication in infancy. New York, NY: Academic Press.

Bates, E., Dale, P., \& Thal, D. (1995). Individual differences and their implications for the theories of language development. In P. Fletcher \& B. MacWinney (Eds.), The handbook of child language (pp. 96-151). Oxford: Blackwell.

Bavin, E. L., Prior, M., Reilly, S., Bretherton, L., Williams, J., Eadie, P., ... \& Ukoumunne, O. C. (2008). The Early Language in Victoria Study: predicting vocabulary at age one and two years from gesture and object use. Journal of Child Language, 35, 687-701.

Bayley, N. (1993). Bayley Scales of Infant Development: manual. San Antonio, TX: The Psychological Corporation.

Bayley, N. (2006). Bayley Scales of Infant Development and Toddler Development: technical manual. San Antonio, TX: The Psychological Corporation. 
Bem, S., \& Keijzer, F. (1996). Recent changes in the concept of cognition. Theory \& Psychology, 6, 449-469.

Benassi, E., Savini, S., Iverson, J. M., Guarini, A., Caselli, M. C., Alessandroni, R., ... \& Sansavini, A. (2016). Early communicative behaviors and their relationship to motor skills in extremely preterm infants. Research in Developmental Disabilities, 48, 132-144.

Bernardis, P., \& Gentilucci, M. (2006). Speech and gesture share the same communication system. Neuropsychologia, 44, 178-190.

Biringen, Z., Emde, R. N., Campos, J. J., \& Appelbaum, M. I. (1995). Affective reorganization in the infant, the mother, and the dyad: the role of upright locomotion and its timing. Child Development, 66, 499-514.

Blaga, O. M., Shaddy, D. J., Anderson, C. J., Kannass, K. N., Little, T. D., \& Colombo, J. (2009). Structure and continuity of intellectual development in early childhood. Intelligence, 37, 106-113.

Bornstein, M. H., \& Lamb, M. E. (2011). Developmental science: an advanced textbook (6th ed.). New York, NY: Psychology Press.

Browne, M. W., \& Cudeck, R. (1993). Alternative ways of assessing model fit. In K. A. Bollen \& J. S. Long (Eds.), Testing structural equation models (pp. 136-162). Newbury Park, CA: Sage Publications.

Bruner, J. S. (1977). Early social interaction and language acquisition. In H. R. Schaffer (Ed.), Studies in mother-infant interaction (pp. 271-289). London: Academic Press.

Burns, W. J., Burns, K. A., \& Kabacoff, R. I. (1992). Item and factor analyses of the Bayley Scales of Infant Development. Advances in Infancy Research, 7, 199-214.

Burns, Y., O’Callaghan, M., McDonell, B., \& Rogers, Y. (2004). Movement and motor development in ELBW infants at 1 year is related to cognitive and motor abilities at 4 years. Early Human Development, 80, 19-29.

Bushnell, E. W., \& Boudreau, J. P. (1993). Motor development and the mind: the potential role of motor abilities as a determinant of aspects of perceptual development. Child Development, 64, 1005-1021.

Campos, J. J., Anderson, D. I., Barbu-Roth, M. A., Hubbard, E. M., Hertenstein, M. J., \& Witherington, D. (2000). Travel broadens the mind. Infancy, 1, 149-219.

Case-Smith, J. (1996). Fine motor outcomes in preschool children who receive occupational therapy services. American Journal of Occupational Therapy, 50, 52-61

Caselli, M. C., Rinaldi, P., Stefanini, S., \& Volterra, V. (2012). Early action and gesture "vocabulary" and its relation with word comprehension and production. Child Development, 83, 526-542.
Christie, S., \& Gentner, D. (2012). Language and cognition in development. In M. J. Spivey et al. (Eds.), The Cambridge handbook of psycholinguistics (pp. 653-673). Cambridge: Cambridge University Press.

Chung, H. J., Eun, B. L., Kim, H. S., Kim, J. K., Shin, S. M., Lee, J. H., ... \& Oh, K. J. (2014). The validity of Korean Ages and Stages Questionnaires (K-ASQ) in Korean infants and children. Journal of Korean Child Neurology Society, 22, 1-11.

Cole, D. A., \& Maxwell, S. E. (2003). Testing mediational models with longitudinal data: questions and tips in the use of structural equation modeling. Journal of Abnormal Psychology, 112, 558-577.

Colombo, J., Mitchell, D. W., Dodd, J., Coldren, J. T., \& Horowitz, F. D. (1989). Longitudinal correlates of infant attention in the paired-comparison paradigm. Intelligence, 13, 33-42.

Dale, P. S., Bates, E., Reznick, J. S., \& Morisset, C. (1989). The validity of a parent report instrument of child language at twenty months. Journal of Child Language, 16, 239-249.

Damon, W., \& Lerner, R. M. (2006). Handbook of child psychology (6th ed.). Hoboken, NJ: John Wiley \& Sons.

Dezoete, J. A., MacArthur, B. A., \& Tuck, B. (2003). Prediction of Bayley and Stanford-Binet Scores with a group of very low birthweight children. Child: Care, Health and Development, 29, 367-372.

Ejiri, K. (1998). Relationship between rhythmic behavior and canonical babbling in infant vocal development. Phonetica, 55, 226-237.

Fagan, J. F., Holland, C. R., \& Wheeler, K. (2007). The prediction, from infancy, of adult IQ and achievement. Intelligence, 35, 225-231.

Gibson, E. J. (1982). The concept of affordances in development: the renascence of functionalism. The Concept of Development: The Minnesota Symposia on Child Psychology, 15, 55-81.

Goodwyn, S. W., \& Acredolo, L. P. (1993). Symbolic gesture versus word: is there a modality advantage for onset of symbol use? Child Development, 64, 688-701.

Goodwyn, S. W., \& Acredolo, L. P. (1998). Encouraging symbolic gesture: a new perspective on the relationship between gesture and speech. New Directions for Child and Adolescent Development, 79, 61-73.

Gyurke, J. S., Lynch, S. J., Lagasse, L., \& Lipsitt, L. P. (1992). Speeded items: what do they tell us about an infant's performance? Advances in Infancy Research, 7, 215-225.

Heo, K. H., Squires, J., Lee, S. Y., \& Lee, J. S. (2006). K-ASQ (Korean-Ages and Stages Questionnaires): parent-completed development screening tool. Seoul: Seoul Community Rehabilitation Center. 
Hoff, E. (2005). Language development (3rd ed.). Belmont, CA: Cengage Learning.

Hong, S. D. (2016). Analysis of longitudinal relation of phonological awareness and word recognition using autoregressive cross-lagged modeling. Journal of Korea Elementary Education, 27, 401-421.

Iverson, J. M. (2010). Developing language in a developing body: the relationship between motor development and language development. Journal of Child Language, 37, 229-261.

Iverson, J. M., \& Thelen, E. (1999). Hand, mouth and brain. The dynamic emergence of speech and gesture. Journal of Consciousness Studies, 6, 1940 .

Iverson, J. M., Hall, A. J., Nickel, L., \& Wozniak, R. H. (2007). The relationship between reduplicated babble onset and laterality biases in infant rhythmic arm movements. Brain and Language, 101, 198-207.

Johnson, M. (1987). The body in the mind. Chicago, IL: University of Chicago Press.

Kelly, M. H., \& Martin, S. (1994). Domain-general abilities applied to domainspecific tasks: sensitivity to probabilities in perception, cognition, and language. Lingua, 92, 105-140.

Kim, J. W., Kim, M. K., \& Hong, S. H. (2009). Writing articles with structural equation models. Seoul: Communication Books.

Kline, R. B. (2015). Principles and practice of structural equation modeling (2nd ed.). New York, NY: Guilford Publications.

Kohen-Raz, R. (1967). Scalogram analysis of some developmental sequences of infant behavior as measured by the Bayley Infant Scale of Mental Development. Genetic Psychology Monographs, 76, 3-21.

Koopmans-van Beinum, F. J., \& van der Stelt, J. M. (1986). Early stages in the development of speech movements. In B. Lindblom \& R. Zetterstrom (Eds.), Precursors of early speech (pp. 37-50). London: Palgrave Macmillan UK.

Kotwica, K. A., Ferre, C. L., \& Michel, G. F. (2008). Relation of stable handuse preferences to the development of skill for managing multiple objects from 7 to 13 months of age. Developmental Psychobiology, 50, 519529.

Lee, J. M. (2010). 'Embodied Cognition' paradigm in cognitive science and convergence across disciplines: implications of connecting new approach in cognitive science and philosophy. Philosophical Ideology, 38, 27-66.

Lee, J. Y., \& Chang, Y. K. (2005). The vocabulary development in early infancy: the short-term longitudinal study from 8-18 month. Journal of Korean Developmental Psychology, 18, 105-123.

Lee, J. Y., Kim, Y. T., Bang, H. J., \& Lee, S. H. (2014). A preliminary study on standardizing the K-Bayley-III Expressive Communication Scale. Com- munication Sciences \& Disorders, 19, 320-330.

Lee, Y. J., Bang, H. J., \& Lee, S. H. (2009). A preliminary study for the standardization of the Korean expressive communication scale of the Bayley Scales of Infant and Toddler Development, third edition. Korean Journal of Developmental Psychology, 22, 59-77.

Lee, Y. (2011). The relationships among language, communicative abilities and motor, cognitive, and socio-emotional development in toddlers with language delays. Korean Journal of Communication \& Disorders, 16, 1-12.

Locke, J. L., Bekken, K. E., McMinn-Larson, L., \& Wein, D. (1995). Emergent control of manual and vocal-motor activity in relation to the development of speech. Brain and Language, 51, 498-508.

MacWhinney, B. (1987). The competition model. In B. MacWhinney (Ed.), Mechanisms of language acquisition (pp. 249-308). Hillsdale, NJ: Erlbaum.

McCall, R. B. (1983). A conceptual approach to early mental development. In M. Lewis (Ed.), Origins of Intelligence (pp. 107-133). New York, NY: Plenum.

McCall, R. B., Eichorn, D. H., \& Hogarty, P. S. (1977). Transition in early mental development. Monographs of the Society for Research in Child Development, 42, 1-108.

McNeil, D. (1992). Hand and mind: what gestures reveal about though. Chicago, IL: University of Chicago Press.

Miller, S. (1987). Developmental research methods. New York, NY: Prentice Hall.

Molfese, V. J., \& Acheson, S. (1997). Infant and preschool mental and verbal abilities: how are infant scores related to preschool scores? International Journal of Behavioral Development, 20, 595-607.

Oller, D. K., \& Eilers, R. E. (1988). The role of audition in infant babbling. Child Development, 59, 441-449.

Owens, R. E. (2012). Language development: an introduction (8th ed.). Newmarket, ON: Pearson Education.

Park, H. J., \& Lee, J. S. (2013). Longitudinal mediation analysis using latent growth curve modeling and autoregressive cross-lagged modeling: mediation effects of self-esteem in the influence of parent-child relationship to depression. Journal of Educational Evaluation, 26, 83-106.

Park, H. W., \& Cho, B. H. (2006). Korean Bayley Scales of Infant Development (K-BSID-2). Seoul: Kidzpop.

Parladé, M. V., \& Iverson, J. M. (2011). The interplay between language, gesture, and affect during communicative transition: a dynamic systems approach. Developmental Psychology, 47, 820-833.

Piaget, J. (1970). Piaget's theory. In P. H. Mussen (Ed.), Carmichael's manual 
of child psychology (3rd ed., pp. 703-732). New York, NY: Wiley.

Reznick, J. S., \& Goldsmith, L. (1989). A multiple form word production checklist for assessing early language. Journal of Child Language, 16, 91-100.

Reznick, J. S., Corley, R., \& Robinson, J. (1997). A longitudinal twin study of intelligence in the second year. Monographs of the Society for Research in Child Development, 62, i-160.

Rose, S. A., Feldman, J. F., \& Jankowski, J. J. (2004). Dimensions of cognition in infancy. Intelligence, 32, 245-262.

Rose, S. A., Feldman, J. F., Jankowski, J. J., \& Van Rossem, R. (2012). Information processing from infancy to 1lyears: continuities and prediction of IQ. Intelligence, 40, 445-457.

Shatz, M. (1994). Theory of mind and the development of social-linguistic intelligence in early childhood. In C. Lewis \& P. Mitchell (Eds.), Children's early understanding of mind: origins and development (pp. 311-329). New York, NY: Psychology Press.

Shrout, P. E., \& Bolger, N. (2002). Mediation in experimental and nonexperimental studies: new procedures and recommendations. Psychological Method, 7, 422-445.

Siegel, D. J. (2012). The developing mind: How relationships and the brain interact to shape who we are. New York, NY: Guilford Publications.

Siegel, L. S. (1983). Correction for prematurity and its consequences for the assessment of the very low birth weight infant. Child Development, 54, 11761188 .

Slater, A., Cooper, R., Rose, D., \& Morison, V. (1989). Prediction of cognitive performance from infancy to early childhood. Human Development, 32, 137-147.

Soska, K. C., Adolph, K. E., \& Johnson, S. P. (2010). Systems in development: motor skill acquisition facilitates three-dimensional object completion. Developmental Psychology, 46, 129-138.

Squires, J., Potter, L., \& Bricker, D. (1999). The ASQ user's guide for the Ages \& Stages Questionnaires: a parent-completed, child-monitoring system (2nd ed.). Baltimore, MD: Paul H Brookes Publishing.

Sung, H. R., \& Bea, K. J. (2004). The longitudinal study on the developmental change of object permanence and its relationship to exploration behavior, cognitive ability and environmental variables. Korean Journal of Developmental Psychology, 17, 21-36.

Sung, H. R., Bea, K. J., Kwak, K. J., Chang, Y. K., \& Sim, H. O. (2005). Prediction of 17-month-old infants' global intelligence from 6-month-old infants' visual recognition memory and specific cognitive abilities. Korean Journal of Developmental Psychology, 18, 1-15.

Thal, D. J., \& Katich, J. (1996). Predicaments in early identification of specific language impairment: does the early bird always catch the worm? In K. N. Cole et al. (Eds.), Assessment of communication and language (pp. 1-28). Baltimore, MD: Paul H Brookes Publishing.

Thal, D. J., \& Tobias, S. (1992). Communicative gestures in children with delayed onset of oral expressive vocabulary. Journal of Speech, Language, and Hearing Research, 35, 1281-1289.

Thelen, E. (1979). Rhythmical stereotypies in normal human infants. Animal Behaviour, 27, 699-715.

Thelen, E., \& Corbetta, D. (1994). Exploration and selection in the early acquisition of skill. International Review of Neurobiology, 37, 75-102.

Uzgiris, I. C., \& Hunt, J. (1989). Assessment in infancy: ordinal scales of psychological development. Chicago, IL: University of Illinois Press.

Volterra, V., Caselli, M. C., Capirci, O., \& Pizzuto, E. (2005). Gesture and the emergence and development of language. In M. Tomasello \& D. I. Slobin (Eds.), Beyond nature-nurture: essays in honor of Elizabeth Bates (pp. 3-40). New York, NY: Psychology Press.

Vygotsky, L. S. (1962). Thought and language. Cambridge, MA: MIT Press.

Wang, M. V., Lekhal, R., Aarø, L. E., \& Schjølberg, S. (2014). Co-occurring development of early childhood communication and motor skills: results from a population-based longitudinal study. Child: Care, Health and Development, 40, 77-84.

Wijnroks, L., \& van Veldhoven, N. (2003). Individual differences in postural control and cognitive development in preterm infants. Infant Behavior and Development, 26, 14-26. 


\section{국문초록}

\section{언어 및 인지발달이 12 개월 영아기 지능에 미치는 영향: 소근육운동발달의 종단매개효과 정미라 $\cdot$ 이순행 $\cdot$ 김종훈 ${ }^{3}$ \\ ${ }^{1}$ 가천대학교 유아교육과, ${ }^{2}$ 가천대학교 세살마을 SSK연구센터, ${ }^{3}$ 경남과학기술대학교 아동가족학과}

배경 및 목적: 본 연구는 영아기의 언어발달을 인지발달 및 소근육운동발달과의 관계에서 종단적으로 살펴보고, 이들 발달영역 간 관 련성이 12 개월의 영아기 지능(MDI)에 미치는 구조적 관계를 살펴보고자 하였다. 방법: 본 연구는 114 명의 영아를 대상으로, 6 개월과 9 개월에는 K-ASQ를 통해 영아의 언어, 인지, 소근육운동발달을 각각 측정하였으며, 12 개월에는 한국형베일리영유아발달검사 제 2 판 (K-BSID-II)을 통해 영아기 지능(MDI)을 측정하였다. 6개월과 9개월의 측정치들 간의 자기회귀와 교차지연 관련성을 살펴보았고, 이 들 측정치로 12 개월의 영아기 지능을 예측하는지 살펴보기 위하여 경로분석을 통해 자기회귀교차지연모형을 검증하였다. 결과: 6 개월 의 언어와 인지발달은 각각 9 개월의 언어와 인지발달에 유의미하게 영향을 미치며 시간 경과에 따라 안정적인 특성을 보였다. 6 개월의 인지발달은 9 개월의 소근육운동발달을 매개로 하여 12 개월의 영아기 지능을 유의미하게 예측하는 것으로 나타났으며, 완전매개모형 을 지지하였다. 6 개월의 언어발달은 9 개월의 소근육운동발달을 매개로 하여 12 개월의 영아기 지능을 유의미하게 예측하는 것으로 나 타났으며, 부분매개모형을 지지하였다. 또한, 언어발달이 모형에 투입되자 9 개월의 인지기술과 12 개월의 영아기 지능 간의 관련성은 더 이상 유의미하지 않았다. 논의 및 결론: 본 연구의 결과를 토대로 12 개월의 영아기 지능에 영향을 미치는 영아기 언어의 역할을 논의하 였으며, 특별히 소근육운동의 매개효과에 초점을 두어 체화된 인지 관점에서 언어와 소근육운동발달 간의 관련성에 대해 살펴보았다.

핵심어: 언어발달, 인지발달, 소근육운동발달, 종단매개효과, 영아기 지능

본논문은2016년도 정부재원(교육부 인문사회연구역량강화사업비)으로 한국연구재단의 지원을 받아연구되었음(No.NRF-2016S1A3A2925502).

\section{참고문헌}

김주환, 김민규, 홍세희(2009). 구조방정식모형으로 논문 쓰기. 서울: 커뮤니케이션북스.

박현정, 이진실(2013). 잠재성장모형과 자기회귀교차지연모형을 활용한 종단매개효과 검증. 교육평가연구, 26, 83-106.

박혜원, 조복희(2006). 한국 베일리영유아발달검사 제2판(K-BSID-II). 서울: 키즈팝

성현란, 배기조(2004). 영아의 대상영속성의 발달적 변화와 이의 탐색행동 및 인지능력과의 관계에 대한 종단적 연구. 한국심리학회지: 발달, 17, 21-

36.

성현란, 배기조, 곽금주, 장유경, 심희옥(2005). 친숙화-새로운 자극 선호 절차를 통한 6개월 영아의 재인 능력과 특수 인지 능력의 17 개월 영아 IQ에 대한 예측. 한국심리학회지: 발달, 18, 1-15.

이유진, 방희정, 이순행(2009). 베일리 영유아 발달검사 3판 표현언어 척도의 한국 표준화를 위한 예비연구. 한국심리학회지: 발달, 22, 59-77.

이윤경(2011). 언어발달지체 영유아의 언어 및 의사소통 능력과 인지, 운동 및 사회성 발달과의 관계. 언어청각장애연구, 16, 1-12.

이정모(2010). ‘체화된 인지(Embodied Cognition)' 접근과 학문간 융합. 철학사상, 38, 27-66.

이지연, 김영태, 방희정, 이순행(2014). 한국형 베일리 영유아 발달검사 제3판 표현언어척도 예비연구. 언어청각장애연구, 19, 320-330.

이지연, 장유경(2005). 영아초기 어휘발달의 특성. 한국심리학회지: 발달, 18, 105-123.

정희정, 은백린, 김현식, 김진경, 신손문, 이지훈, 최지은, 김영아, 오경자(2014). 한국형 부모 작성형 유아모니터링체계(Korean Ages and Stages Questionnaires: K-ASQ)의 타당도 평가. 대한소아신경학회지, 22, 1-11.

허계형, J. Squires, 이소영, 이준석(2009). K-ASQ 사용 지침서(2판). 서울: 서울장애인종합복지관.

홍성두(2016). 자기회귀교차지연모형을 적용한 학령 전 아동의 음운인식과 단어재인의 종단적 관계 분석. 한국초등교육, 27, 401-421. 